\title{
Promote Folksong Use Game Based On Augmented Reality
}

\author{
Baskara Arya Pranata, \\ Soegijapranata Catholic University \\ supertr4mp3@gmail.com \\ Ridwan Sanjaya, \\ Soegijapranata Catholic University \\ ridwan@unika.ac.id \\ Albertus Dwi Yoga W \\ Soegijapranata Catholic University \\ yoga@unika.ac.id
}

\begin{abstract}
Abstact- folk songs in indonesia's is wealth cultural heritage most of our ancestors. In this modern era narrower the knowledge of their own folk songs due to the influx of foreign cultures.

Augmented is a new technology to display digital visual in the real world. This technology is very interesting when applied in the field of entertainment. This Research Report contains about how to create a game titled Tembang which aims to preserve the songs of the region that originated from the Indonesian. In this game will provide information about the local songs along with their origin, packed in Augmented Reality technology, with challenge quizzes, and there is a gift feature to make players interested in completing the game.

Keywords: Folk song, Augmented Reality, games, quiz.
\end{abstract}

\section{PROLOGUE}

Folk songs are songs that were created in a certain area and is often sung by local people who are regional relic in it, usually use the language of the area[1]. But the unfortunate young man currently Indonesia is hardly acquainted with its territory of its own. Plus there is no means of information support for the introduction of folk songs. But in Indonesia there are virtually hundreds of folk songs are no less good with the song-a modern song.

In this Era, almost the entire community using smartphones. All information and all sorts of entertainment can all be enjoyed from gadget smartphone[2]. Therefore authors will use the smartphone as a media play and learn. Therefore be invented Game guess with Augmented reality will provide information and introducing folk songs interactively. Created with the theme fun so make all users easily know and remind folk songs. Based on the background of the formulation of the problem then as follows:

1. How formulations folk songs game based on Augmented reality?

2. How in-game scenario folksongs based on Augmented reality?

3. How to reward and punishment in order that players interested will know the folk songs in the game?

\section{A REVIEW OF THE LITERATURE}

A few things in mind before making the game, among other things:

\section{A. Video Games}

video games have a variety of genre or can also be called a range of game types namely sorts - action games, adventure games, fighting games, role-playing games, 
simulations, sport games, and strategy games. Most people assume that the game it teaches violence and activities that are meaningless. Whereas games can also affect the aggressiveness and social sciences, as well as there are many positive things that can be learned. Like his thing happening now game simulation is necessary to solve the problem or to conduct research. Video games can be used as a very effective learning tool that meets the demands of users who are interested in and involved with the content.

\section{B. Music Of Indonesia}

Indonesia music is music that has been adopted and adapted in the past that have spread throughout the area tradition roots area of Indonesia. There are two categories of music that exists in Indonesia, the first traditional music from different areas, such as music, gamelan angklung, calung, talempong, tarling, and others. Then the second, the music that originally from overseas, but has become a community tradition of Indonesia, Kroncong, dangdut music, Malay, and other [3].

\section{Quis Game}

Quiz is a game that can provide facts and information, and offers an easy assessment Quiz game helps players to sharpen memory and train the brain [4].

\section{Augmented Reality}

Augmented reality (AR) is often referred to by a combination of virtual objects into the real world. The hallmark feature of the AR itself - is:

1. A joint Virtual and Real

2. Interaction in Real time.

3. Have a 3D object [5].

\section{E. Unity3D}

Unity3D is a perfect choice for the startup, indie developers, and everyone who wants to make their own games.
To be able to create the folk song game-based Augmented Reality and aim so that players are more interested in, things to note are:

\section{A. Popular game observations}

Education game are already popular is "Who wants to be a millionare". This Game is a Trivia. So which player to answer multiple choice questions that are already provided by the author.

\section{B. Determination of the types of games}

From the observations are already made, to create the folk game-based on Augmented Reality it was decided the kind of trivia quiz game. Because many people like Trivia Quis and easy to play.

\section{Technical Game Development}

Technically the formulation of gamebased Augmented Reality folk songs have 3 core subjects will be displayed in Augmented Reality (AR) is Video, 3D models, and folk songs. Where in the game will display the area in the song down in video and features a 3D model in appear in Augmented Reality (AR). To display the AR marker requires as a trigger.

In the making of this game needs some software such as Unity3D, Vuforia, Frutyloops, Camtasia Portable, Sai, and Adobe Photoshop.

\section{GAMEPLAY}

Gameplay folk song game that is where players in require to know folk songs along with the origin, and gathers as much value- the number to be exchanged for gifts.

\section{DISCUSSION}




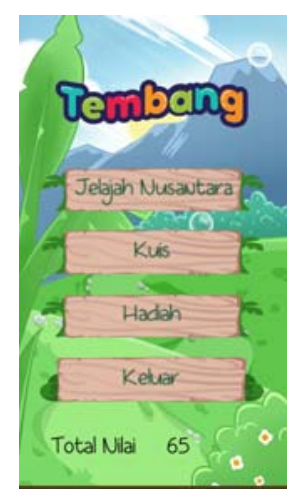

Picture 1. Game Tembang

In this game have an Archipelago Cruise menu served in Augmented Reality where players must target camera to books containing images of the map and displays a video of the song.

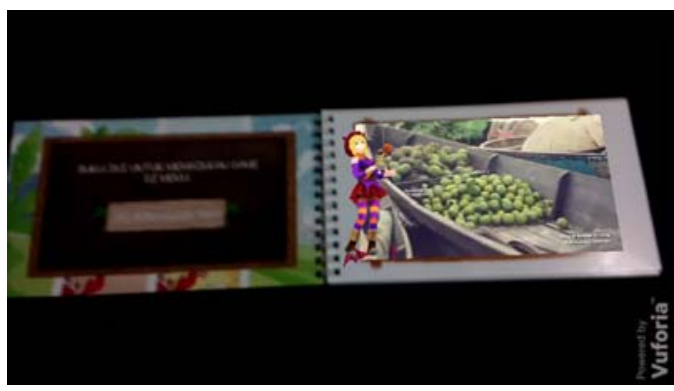

Picture 2. Jelajah Nusantara

Menu quiz challenging players to answer quiz questions about the song title or the origin areas, when answering correctly will get a value and if the answer is wrong it will reduce opportunity. Players only get 3 chances, when chance runs out then the game will be finished.

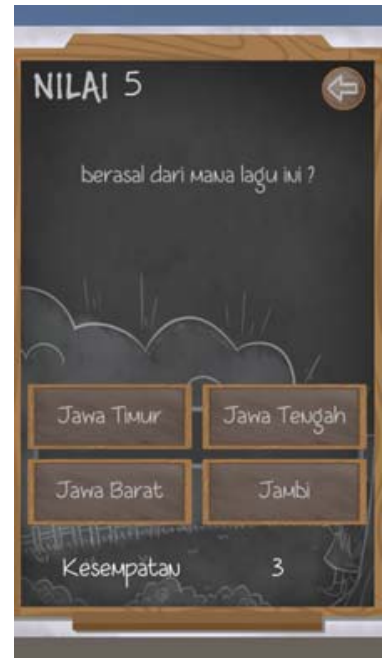

Picture 3. Kuis

The menu of Gifts is the place to exchange points gained from the games quiz. Each prize has a value of requirements to get him. Gifts of theme background where players can change the theme as you wish.

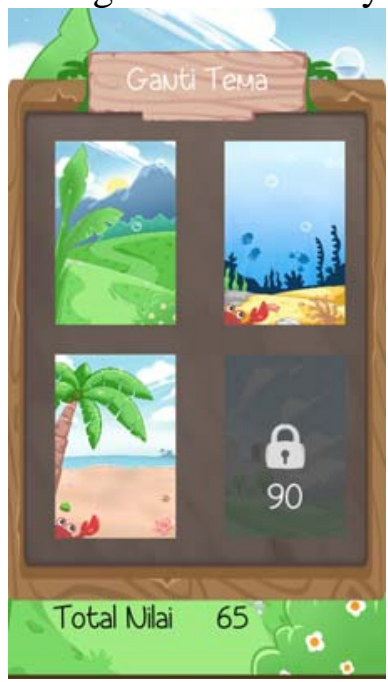

Picture 4. Hadiah

\section{E. SURVEY}

After the game, so researchers did survey testing games and spread the questionnaire to get the data. In this study, targets population data collection is the general public who love to play the game. Samples taken as many as 30 people.

Following is the result from the survey questionnaire is playing games:

1. Interesting game-based folk songs based on Augmented Reality in terms of gameplay?

From these questions the answers of the respondents answered strongly agree $83.3 \%$, and the rest is $16.7 \%$ answered agree.
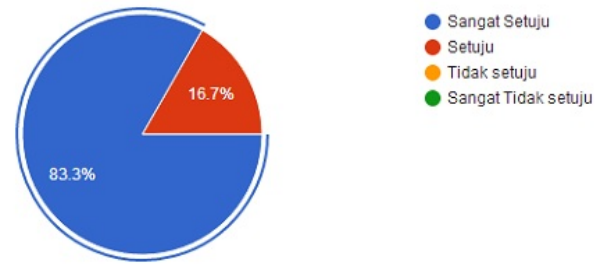

Picture 5. the results of the questionnaire is interesting in terms of the game

2. Interesting game-based folk songs based on Augmented Reality in terms of design? 
In terms of the design of $63.3 \%$ of respondents answer answer strongly agree, and the rest is $36.7 \%$ answered agree.
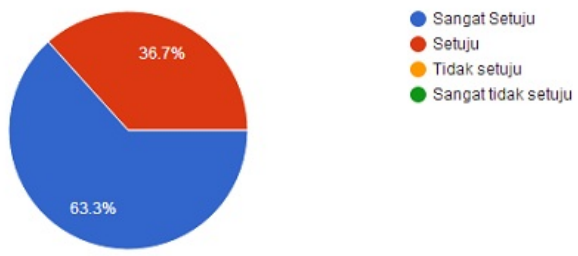

Picture 6. the results of the questionnaire attractive in terms of design

3. Interesting game-based folk songs based on Augmented Reality in terms of game flow?

In terms of the gameplay results survey $70 \%$ answered strongly agree, $26.7 \%$ agree, and 3.3\% answered don't agree.
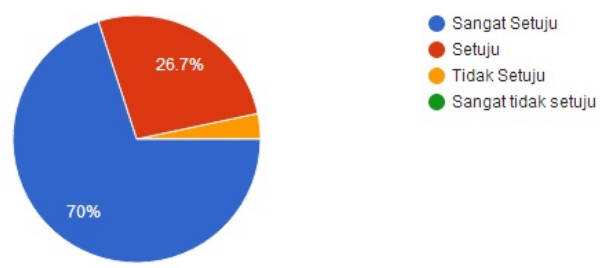

Picture 7. the results of the questionnaire is interesting in terms of the game

4. How your highest value in the game?

From the survey results of the highest rated players $80-100$ amounted to $6.7 \%$, then that gets the value of $60-80$ amounted to $36.7 \%$, then the value of $40-60$ amounts to $30 \%$, and the rest are getting value of 5-40 amounted

to

$26.7 \%$.

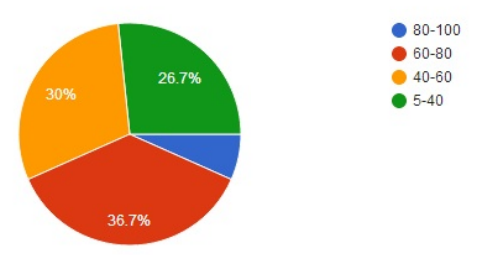

Picture 8. the results of a questionnaire how the highest value in the game

5. How the level of your interest to complete the game?

Respondents answered very interested amounted to $6.7 \%$, then answer interested amounted to $83.3 \%$, and the remaining $10 \%$ not answering.

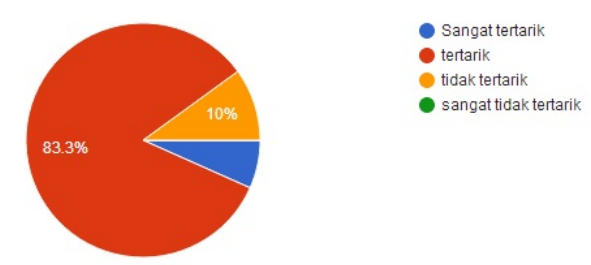

Picture 9. the results of a questionnaire completed attraction game

6. How big is your interest in the feature Prize in the game?

From the menu presents the interest of respondents 20\% responded very interested, 66.7\% 13.3\% interested, answer the answer is not interested

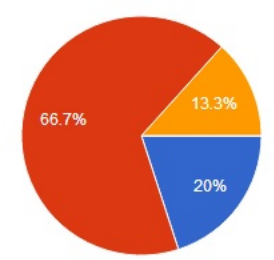

- Sangat tertarik

tertarik

tidak tertarik

- sangat tidak tertarik

Picture 10. the results of the questionnaire on the feature attraction gifts

7. Are you agree game-based Augmented Reality can help preserve folk songs?

Respondents expressed strongly agree of $96.7 \%$, and the rest of $3.3 \%$ answered agree.

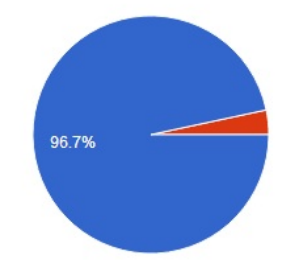

- Sangat setuju

tidak setu

sangat tidak setuju

Picture 11. results of questionnaire games help preserve folk songs

8. How many songs that you know in the game?

Respondents answered this question from $3.3 \% 15-20$ knew the songs, then $43.3 \%$ know the $10-15$ song, $46.7 \%$ knowing the 5-10 the song, and the rest are $6.7 \%$ know the 1-5 song. 


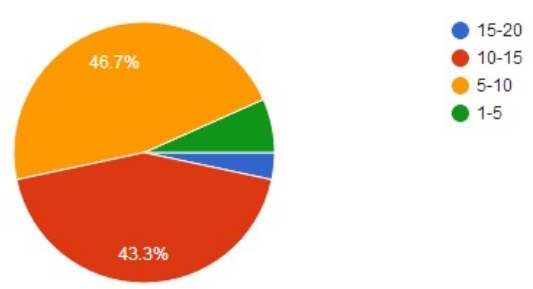

Picture 12. the results of the questionnaire several songs in the know

9. How hard is it to play the game?

For the makers of this game is made as easy as possible to be played but $6.7 \%$ of survey results respondents answer very easily, $66.7 \%$ replied easily, $23.3 \%$ answer difficult, and the rest was 3.3\% answering very difficult.

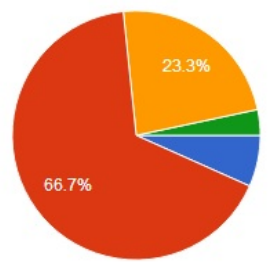

- Sangat mudah

- mudah

- sulit

- sangat sulit

Picture 13. the results of a questionnaire how difficult game to play

10. How like you on this game? The result of the survey is arguably all liked this game because of the percentage of visible $26.7 \%$ answering very fond, and the rest $73.3 \%$ responded like.
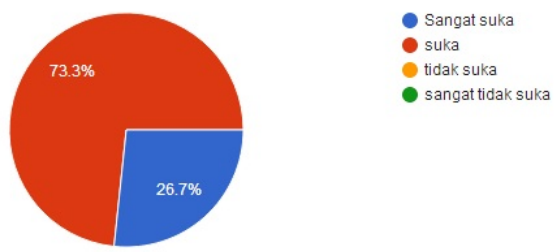

Picture 14. the results of a questionnaire how like this game

\section{CONCLUSION}

In this research, "the formulation of folk forms of Augmented Reality" that make AR using the software Vuforia. Target marker using an image map as a trigger to bring up the video clip of the song 3D characters and areas of Augmented Reality.
Things to note when the appearance of the AR that is a fairly light conditions in a place

or room. Then to get a good performance when playback of the videos, each one storing a maximum of Augmented Reality scene 5 video will be on show.

In this study "scenario folk song game based Augmented reality" genre trivia quiz, The player must follow the flow of the game in order. To know the folk songs along with the originally present in the Archipelago Cruise menu presented in Augmented reality. Then in the quiz menu, the challenge for players how to know the local songs along with the origin to get the best value to be exchanged prizes that have been provided.

From the research results of this game survey is very interesting to play. In terms of features, there is a positive answer from the players. This game is also easy to play, then very helpful to preserve the songs of the region in Indonesia.

\section{REFERENCE}

[1] W. Purnomo and F. Subagyo, Terampil Bermusik. Pusat Perbukuan Kementrian Pendidikan Nasional, 2010.

[2] S. Juraman, "Pemanfaatan Smartphone Android Oleh Mahasiswa Ilmu Komunikasi Dalam Mengakses Informasi Edukatif,” J. ACTA DIURNA, 2014.

[3] I. Ghozali, "Pembelajaran Musik Berbasis Siswa," FKIP Untan, pp. 651-663, 2011.

[4] K. Anagnostou and A. Pappa, "Video Game Genre Affordances for Physics Education,” Int. J. Game-Based Learn., vol. 1, no. March, pp. 59-74, 2011.

[5] T. Domhan and K. TIT07INA, "Augmented reality on android smartphones,” Studiengangs, 2010. 